Placing "Matter Out Of Place": Purity and Danger as Evidence for Architecture and Urbanism

\title{
Ben Campkin
}

This paper revisits Mary Douglas' Purity and Danger: An Analysis of Concepts of Pollution and Taboo (1966). A survey of this theory in architecture in the latetwentieth century reveals how it focused attention on relationships between dirt, cleanliness, and the design and organisation of space - an area previously neglected in architectural thought. Dirt remains an important focus within architectural and urban theory, with implications for practice. Yet, the intersections that scholars of the 1980s and 1990s made between Douglas' work and critical theory, feminist and psychoanalytic writings elicited problems with her structuralist approach that remain unresolved. These are apparent in considering relationships between dirt and cities indeed, the aphorism Douglas invokes, 'dirt is matter out of place', originates in discussions of nineteenth-century urbanisation. To better understand dirt's relationships with modern and late-modern capitalist cities, Douglas' insights can be productively read alongside post-structuralist accounts, including the psychoanalytic notion of the abject and recent neo-Marxian scholarship on the production of urban nature.

\section{Correspondence:}

Dr Ben Campkin

UCL Urban Laboratory

University College London

Wates House

22 Gordon Street

London

WC1H 0QB

Email: b.campkin@ucl.ac.uk

Twitter: @BenCampkin

Web: http://www.ucl.ac.uk/urbanlab/people 


\section{Placing "Matter Out Of Place": Purity and Danger as Evidence for Architecture and Urbanism}

\section{Ben Campkin}

If we can abstract pathogenicity and hygiene from our notion of dirt, we are left with the old definition of dirt as matter out of place. ${ }^{1}$

-- Mary Douglas (1921-2007).

\section{Introduction}

Few anthropological texts can have had so notable an impact outside of that discipline, and on the discipline of architecture in particular, as Mary Douglas's Purity and Danger: an analysis of concepts of pollution and taboo, first published in 1966. ${ }^{2}$ Until the late 1970s, this text by Douglas - an exploration of social and cultural systems through the evidence of the everyday, the excluded and the prohibited - was itself considered marginal within the discipline of anthropology; and later in life she revealed that she was disappointed with the immediate response. ${ }^{3}$ Subsequently, however, Purity and Danger went on to become an exemplar of the power of theory to cut across disciplines, methodological approaches, and intellectual positions; helping us to understand dirt in varied material and symbolic forms. This text has productively opened architecture up to the broader fields of contextual evidence considered within anthropological and material culture scholarship. In this paper I will revisit a selection of Douglas-inspired architectural and urban scholarship from the 1980s and 1990s, showing how her theory was used at multiple scales,, from interior design to the urban fabric, in the process elucidating the relationship of design to ideas of dirt and cleanliness.

For architectural theory and practice dirt remains a lively topic of debate today. ${ }^{4}$ In this context, what does Douglas's theory still offer, and particularly in regard to urban questions? A brief survey of earlier interpretations of Douglas's theory will help us to identify some unresolved problems, as well as some possibilities for our understanding of, for example, the displacements that operate through contemporary neoliberal urban redevelopment and the ideological role of 
architecture within its attendant socio-spatial practices of exclusion. Ultimately, what I want to argue here is that it is in relation to capitalist cities and urbanisation that we need to be most careful how we transpose or 'apply' Douglas's theoretical account of dirt. Since dirt is central within processes of urbanization, it is necessary to open up a more hybrid theoretical terrain.

Dirt itself, for Douglas, is a subject that necessitates thinking across different scales of evidence: from everyday materiality to language and cultural symbolism. She looks to dirt to provide evidence for social and cultural systems, constructing arguments about this macro scale through reference to information gathered during empirical anthropological fieldwork, observations of the everyday, reflections on anthropological and other bodies of theory, and ambitious comparisons between different cultures and geographical contexts.

Douglas's theory itself is often taken to be encapsulated in the six-word phrase in Purity and Danger that has become its most famous idea by far: 'dirt is matter out of place'. There is a rhetorical certainty in this seductively simple formula, but what kind of evidence is there to support it? The origins and interpretation of the phrase raise some interesting problems of their own. It is often attributed to Douglas herself. Yet, in the first edition of Purity and Danger it is unreferenced, and in later editions Douglas referenced it to Lord Chesterfield - Philip Dormer Stanhope, 4th Earl of Chesterfield 1694-1773 - without giving an exact source. As Douglas's biographer Richard Fardon has noted, the phrase first appears in Douglas's work in a volume of fieldnotes from her second trip to study the Lele people in the Belgian Congo in 1953, where she writes:

Asked to define dirt in England — Not earth, just simply [dirt]. Contrast: idea of dirt, with 'good clean mud' etc. Chesterfield 'Dirt is any matter displaced' e.g. hair, crowning glory etc. and hair in the soup. But child putting spoon it has licked back in the veg. tureen and told off for being 'dirty'. 'Dirty' is much wider range than just 'dirt'. Any bodily excreta, saliva, vomit, faeces, and anything that has contact with them is dirty. Food is wholesome when served, but as soon as someone has eaten a little, and left it, it is 'orts', remains, dirty.

In this passage we see how Douglas interprets her own observations of everyday life for the Lele people through reference to an idea recalled from her earlier education. We also see the origin of some of Purity and Danger's key themes, and in particular 
the relationship - often contradictory - between symbolic and material dirt and dirtiness. For Douglas, beliefs about what is dirty are determined through inextricably linked bodily sensations, physiological and psychological processes. These appear to be intuitive ('an underlying feeling') or natural. ${ }^{6}$ Yet there is no such thing as absolute dirt - it is a matter of perception and classification. In this understanding, direct links are made between physical states and social codes, between the material and the metaphorical. Oscillating between different understandings of where thought or perception reside, this approach encompasses tensions at its heart between structuralist and phenomenological understandings of dirt.

Frustrated by the lack of an original source for the 'matter out of place' phrase, in writing this paper I sought advice from Fardon. ${ }^{7}$ However, neither Fardon, nor the anthropologist Alan Macfarlane, was able to find a precise reference, and so far we have not located any version of it in Chesterfield's writings. Based on his work as her biographer, Fardon also observes that Douglas was in general careless with referencing. The cultural theorist Steven Connor recently quoted Lord Palmerston Henry John Temple, 3rd Viscount Palmerston, 1784-1865 - as having addressed the Royal Agricultural Society using a similar phrase in 1852: 'I have heard it said that dirt is nothing but a thing in a wrong place. Now, the dirt of our towns precisely corresponds with that definition. ${ }^{8}$ For our purposes, it is interesting that Palmerston here refers to the phrase in relation to the urban environment. Furthermore, as Connor has pointed out, the quote indicates that the phrase was a commonplace, 'which means that it is hard to pin down or put in its proper place'. ${ }^{9}$ It seems most likely that Douglas had heard the aphorism somewhere and misattributed it, in the process inventing her own, more concise and catchier, version. Numerous authors have subsequently popularised Douglas's phrase, often attributing it to her, in spite of her reference to Chesterfield. ${ }^{10}$

What is the value of this dictum as a frame for thinking about dirt or the social systems through which it is controlled? It is almost too easy to repeat it without further critical reflection or contextualisation: it becomes reified. Even if we accept the argument, numerous writers since Douglas have observed, as Fardon notes, 'that the formulation is not reversible: all matter out of place is not dirt'. ${ }^{11}$ For Douglas, as the cultural theorist William Cohen writes, 'Pollution is not simply the opposite of cleanliness; it also arises out of a confusion of categories'. ${ }^{12}$ Yet, as a definition, 'matter out of place' works against this, suggesting dirt to be a stable and clearly 
defined category, rather than a catchall and relative term, and implying a simple binary understanding of the boundary dirty/clean.

It is still useful to think of dirt in terms of placement and displacement, and there is of course more to Douglas's theory than its best known phrase might at first suggest. For Douglas, dirt is ambiguous and anomalous, causing anxiety through disrupting classification systems and the 'normal' ordered relations that one understands the world through; hence, in an essay from the mid-1970s in which she developed the arguments of Purity and Danger, she writes:

For us dirt is a kind of compendium category for all events which blur, smudge, contradict, or otherwise confuse accepted classifications. The underlying feeling is that a system of values which is habitually expressed in a given arrangement of things has been violated. ${ }^{13}$

As may be expected for a structuralist thinker, for Douglas these accepted classifications are necessarily binary, so that 'reflection on dirt involves reflection on the relation of order to disorder, being to non-being, form to formlessness, life to death' ${ }^{14}$

Writing in the tradition of structuralist social anthropology, Douglas read individual pollution beliefs and behaviours, observed through texts and fieldwork, as evidence for understanding social systems. Purity and Danger demonstrates an interest in how culture is embedded in 'the concrete, the mundane', and at a more abstract level in the 'collective ordering of social life' through systems of classification. ${ }^{15}$ Architecture - such as the huts of the Lele - served for Douglas as one category of material evidence to contribute to a 'total' anthropology. In this the researcher embedded herself within an environment characterised by its 'otherness', often for years at a time, in order to understand people in relation to the region in which they lived, their kinship relations, their politics, language, economy, technologies and so on. In her methods and preoccupations Douglas was influential in the development of the field of material culture studies within the discipline of anthropology. In the present moment, it is notable that material culture scholarship is intersecting in creative ways with the disciplines of architecture and architectural history, in the process contributing more fine-grained contextual understandings of architecture's place within social systems, and its agency in relation to other forms of material culture. ${ }^{16}$ 
Douglas's specific method was in some ways a radical departure from her predecessors and teachers in structuralist anthropology. Most remarkably, it featured comparison between dirt constructs and pollution behaviours observed in her 16 months of fieldwork with the Lele, and those of the modern west - often rendered through analogies drawn from her own experience, home life and environment. Later in her life Douglas would attribute this to the fact that she was housebound with mumps and looking after her two children when she wrote the book. Emphatically ordinary, often domestic, metaphors are deployed, suggesting the value, as evidence, of the banal matter of dirt itself, and opening up the topic, in particular, to readers in Douglas's immediate social milieu. ${ }^{17}$ It was through this approach that an uncomfortable reality was exposed: modern western conceptions of dirt, and responses to it, though naturalised and presented as rational, paralleled the superstitious practices attached to primitive religious rituals. ${ }^{18}$

In this comparative method Douglas's theory followed the model of religious social anthropology set out by Émile Durkheim (1858-1917), whose ideas had influenced her teacher at the University of Oxford, E. E. Evans Pritchard (19021973). In placing Purity and Danger within the context of anthropology, we should also note that Claude Lévi-Strauss (1908-2009) had already questioned the categorisation of 'primitive' societies as inferior to modern Western ones, arguing for commonalities between the 'savage' mind and the 'civilized' mind. ${ }^{19}$ In the contributions that Douglas made to the emerging field of social anthropology during her lifetime, it was an important aspect of her work that she bridged between these different continental European and Anglo-American schools of anthropological theory.

In Purity and Danger we see how Douglas draws evidence and analogies from everyday domestic life - that for her, dirt as matter and index operates between the everyday and the ontological. The tendency to ground the broad category of 'dirt' in the terrain of domesticity, as well as an openness to a plurality of meanings derived from a given classification system, mean that Douglas's work does not fit comfortably in the canon of structuralist anthropology. ${ }^{20}$ Rather than a grand meta-theory of dirt, the reader of Purity and Danger is presented with what Douglas describes as 'homely' arguments. ${ }^{21}$ In her preface to the last edition of Purity and Danger printed in her lifetime (2002) Douglas reiterated her view that 'everyone universally finds dirt offensive', while the way it is defined will depend on localised classificatory systems. 
However, she also described the book's arguments as 'convoluted', and noted that it 'made society sound more rigid than it really is'. 22 Although she argues that the definition of dirt is in flux according to different cultural and historical contexts, for Douglas the idea of 'dirt' and our reactions to it are constant. Is this not itself an ahistorical and paradoxical assumption, and an assumption which obscures the changing materialities, effects and perceptions of dirt across time and space? Though challenging to our systems of categorisation and value attribution, dirt clearly does have 'a place' within those systems. As Cohen says, 'contradictory ideas - about filth as both polluting and valuable - can be held at once' (see page 4, above). Furthermore, even when tidied up, put 'in place', some kinds of dirt may retain their threat.

Theories of dirt are in essence theories of order if one accepts Douglas's view that there is no such thing as dirt without classification. ${ }^{23}$ This central interest in order and disorder and their spatialisation finds parallels in the work of Douglas's contemporaries, such as Henri Lefebvre and Michel Foucault, whose poststructuralist writings on order and heterotopia have played a more prominent role in subsequent architectural, urban and spatial thought. Foucault and Douglas have been read alongside each other in geography and cultural theory, if not in architecture. ${ }^{24}$ Although Foucault's and Lefebvre's work have had a more obvious and wider influence in directing subsequent scholars to examine social and spatial processes of exclusion and displacement, Douglas's thinking was also important in this.

The symbolic emphasis in Douglas's understanding of dirt leads her to underscore the visual and spatial characteristics attached to pollution belief systems and practices. ${ }^{25}$ Prohibition is discussed in terms of borders and boundaries, and threats to those borders and boundaries. In her preface to the final edition of Purity and Danger produced in her lifetime Douglas again places emphasis on the spatiality of her subject, writing that 'Taboo is a spontaneous coding practice which sets up a vocabulary of spatial limits and physical and verbal signals to hedge around vulnerable relations'. ${ }^{26}$ In eliminating dirt of all kinds, Douglas argues, we are involved in a perpetual spatial and visual process of arranging and rearranging the environment, 'making the world conform to an idea'. ${ }^{27}$

It follows, then, that there are many areas of spatial investigation in which Douglas's ideas on dirt, and other theories of excluded and degraded matter, may be and have already been - useful, in terms of both physical spaces and spaces of 
representation. At the most literal level, the arguments put forward in Purity and Danger are valuable in the analysis of spaces or infrastructures specifically identified as 'clean' or 'dirty', or constructed to deal with unwanted or polluting matter, such as sacred spaces, medical buildings, bathrooms, or dumps, sewers and cemeteries. Ideas of pollution and strategies for dealing with contaminated materiality are, of course, central in discussions of ecological urbanism and the re-use of ex-industrial buildings and landscapes. Ways of thinking about the ordering of space and specific buildings of different scales are also suggested within this theoretical discourse - zoning and partitioning. The spatialised discussion of prohibition, transgression and punishment provides a platform for exploring the role of the built fabric as a reflection of, or an instrument in the production of, individual, social or cultural ordering systems. Related to this point, beyond practices of hygienism, maintenance, cleaning and waste management, such theories may enable us to better understand the underlying sociocultural and psychological impulses driving the imposition of different conceptions of order and disorder on specific buildings, whole city districts, or urban conditions; or the socio-economic, symbolic and physical 'sanitization' processes associated with urban redevelopment and gentrification.

\section{Purity and Danger in action}

A brief survey of five examples of Douglas's theory as it was used as evidence in architecture and urbanism in the 1980s and 1990s suggests its potentials and limits, and some ways that we might now reorient interdisciplinary work on dirt. Underlying this selective survey - taking some of the most subtle and extended articulations of Douglas's work in the fields of architecture and urbanism - is a concern with how we might understand urban dirt, in particular, and dirt in late modernity, where in certain spheres the excluded and degraded stimulate creativity, or are revered or celebrated.

Firstly, consider the architectural historian Adrian Forty's exploration of the modernist aesthetics of cleanliness in design and interior design history. In Objects of Desire: Design and Society Since 1750 (1986) Forty demonstrates how Douglas's theory can be productive in demystifying the ideologies underpinning modernist hygiene reform and its accompanying products and aesthetic tropes. ${ }^{28}$ He examines the 'imagery of exaggerated hygiene' incorporated into the designs of household objects and interiors, emphasising how these objects actively influenced behaviour and produced new understandings and perceptions of dirt, especially dust. Forty 
shows how the design of specific things and interiors arose from particular Western ideas about dirt and cleanliness, and how practices and aesthetics were shaped by constructions of class and gender. Building on Douglas's theory, he emphasises how the reform of cleaning methods was transmitted through emotional - as well as rational and scientific - arguments, to the benefit of the wealthier classes. Middleclass hygienists mobilised cleanliness, through hygiene reform, as a means of social control, and to ensure the health and longevity of a productive proletariat. ${ }^{29}$

This example illustrates the creative possibilities of using Douglas's theory - and, indeed, the 'material culture studies' anthropological approach, which prioritises the evidence afforded by everyday things and spaces, and that was in part her legacy - to elucidate design in general, and hygiene aesthetics and domesticity in particular. Yet it also highlights that Douglas's own account in some ways worked against its own call for cultural specificity, omitting in its comparative approach an appreciation of the contradictory roles of dirt and pollution taboos within industrial capitalism. As Forty demonstrates, hygiene reform is used to reorganise and discipline the poor, and this is enacted spatially, from the micro-architectural to the city scale, and naturalised through everyday artefacts.

Connecting with Forty's reading of the gendered construction of pollution taboos in domestic contexts, the feminist architect and theorist Katherine Shonfield emphasises Douglas's preoccupation with pollution rules as mechanisms to protect the overall form of society:

Douglas' view is that pollution taboos - rules in society that guard against the unclassifiable, the impure and the hybrid - have a physical expression. This emerges from an image of social well-being as synonymous with clearly delineated physical form, a form which is habitually counterpoised against a sea of potentially threatening and polluting formlessness. ${ }^{30}$

Through texts and installation projects such as 'Purity and tolerance' at the Economist Building in London, Shonfield collaborated with muf architects and others to directly employ the ideas in Purity and Danger, interspersing theory with fictional narratives. 'Purity and tolerance', for example, saw Shonfield inserting a shiny bulging ceiling into a ground floor interior of the Economist Building, alongside a text inscribed onto the window at street level which drew an analogy between the building's cladding and sanitary towels. The point was to draw attention to the 'refusal of both to 
acknowledge in the rigours of their form the presence of the liquid, i.e. the formlessness of both blood and water'. 31

In these works, Douglas's theory is utilised to imaginatively undermine tropes of order in iconic modernist architecture, and its material, constructional and aesthetic tenets. Shonfield describes brutalism as itself a 'quest for purity, expressed by taboos against pollution' that 'permeates architectural and urban practice' ${ }^{32}$ Her extrapolation from Purity and Danger again reinforces the spatiality of Douglas's theory, and its potential to inform critical readings of architectural modernism. Importantly - if implicitly - they highlight the universalising tendency underlying Douglas's theory. She conceives of culture as 'the public, standardised values of a community', and of universes based on 'general principles', assuming shared and agreed rules, codes and ideas across a homogeneous society. ${ }^{33}$ The argument that 'classifying is a human universal' is a core weakness of Douglas's work, constituting an unreflexive variant of a general theory of universality. ${ }^{34}$ These characteristics of Purity and Danger are in tension with Shonfield's feminist deconstruction of modernism. It is also important to note that Shonfield's work creatively used 'dirtying' as a method in design and writing. This is certainly in tune with Douglas's own idiosyncratic and transgressive approach to academic work in which she emphasised 'energy in the margins and unstructured areas'. 35

Mark Cousins's articulation of 'the ugly' provides another extension of Douglas's work on dirt that, like Shonfield's, takes it as evidence to elucidate architectural aesthetics, within a psychoanalytic theoretical framework. ${ }^{36}$ His discussion of ugliness builds on Douglas's spatialised understanding of pollution, but interjecting a heightened sense of movement between given categories and states. He writes that: in so far as dirt is matter out of place it must have passed a boundary, limit or threshold into a space where it should not be. The dirt is an ugly deduction from 'good' space, not simply by virtue of occupying the space, but by threatening to contaminate all the good space around it. In this light, 'dirt', the ugly object, has a spatial power quite lacking in the beautiful object. ${ }^{37}$

As opposed to Douglas's more static understanding of the category of dirt in a rigidly structured world, in Cousins's extrapolation the dirty (ugly) object is not just 'matter out of place' but, being animate or potentially animate, embodies a power to spread. Furthermore, in this theory ugliness is at once excluded from, and also a 'moment' in 
the unfolding of, beauty, within a process of creative production. ${ }^{38}$ These arguments are useful in conceiving of the dynamic relationships between, for example, 'blighted' urban districts, categorised as degraded or polluted, and the purer antitheses they threaten. Cousins argues that such 'negative constructions' provoke in us a reminder of mortality and 'a kind of horror'. ${ }^{39}$ In addition, Cousins points to the ambivalent role of dirt in art and architectural aesthetics. We might usefully extend this line of thinking to capitalist urbanisation, with dirt of various kinds as the raw material of creativity, part of a creative act of production. In this sense we can conceive of dirt - both material and symbolic - as intrinsic to cycles of 'creative destruction', to use the economist Joseph Schumpeter's phrase for describing the incessant processes of wealth creation, destruction and reconstruction fundamental to capitalism in its variegated forms. ${ }^{40}$ Douglas's theory appears ill equipped to deal with the material and metaphorical uses of 'dirt' in the production of the city, or its production through forms of urbanisation that are cyclically and simultaneously destructive and creative.

In a further example of spatial theory from this period, the negative social consequences of stigmatising constructions of dirt were a central focus of geographer David Sibley's interpretation of Douglas in Geographies of Exclusion: Society and Difference in the West (1995). With interests in socio-spatial mechanisms of regulation, Sibley examines images of dirt and cleanliness in media discourses encircling stigmatised places and communities, aligning Douglas's conception order and prohibition with Foucauldian notions of exclusion. ${ }^{41}$ In his account of 'landscapes of exclusion', Sibley is able to show how the spatial marginalisation of matter becomes inextricably linked with the spatial marginalisation of groups of people who, for one reason or another, do not fit comfortably within society's dominant bourgeois social and cultural value systems. Reading Douglas's ideas on prohibition through Foucault enables Sibley to disentangle the complex and often inconsistent operation of ideas about dirt and cleanliness as they shift between discursive and material realms, impacting on particular social groups, where Douglas's own more rigid approach often seems to lack an overt criticality or political position.

A final architectural example of the 'application' of Douglas's theory, this time directly exposing how problematically it reads when we think at the urban scale in late capitalist cities, is provided by the psychogeographic cultural historian Patrick Wright's A Journey Through Ruins: The Last Days of London (1991). Wright's book 
draws on Purity and Danger in its discussion of the social, physical and cultural landscape of London's neglected lower-income Dalston neighbourhood under Thatcherism in the early $1990 \mathrm{~s} .{ }^{42}$ Wright reads Douglas's notion of dirt as 'the domain in which all [...] differences are lost', a broad conceptual category for that which lies 'outside of a culture'. In this he again asserts the value of the excluded and marginalised as evidence, here in an intuitive experiential urban anthropology of degraded and ordinary city streets. ${ }^{43}$ Yet, constructing his historical account of the city through observations made while walking Dalston's streets, he is critical of Douglas's and other abstract 'elegant theories about dirt' for their detachment from everyday life, and the political and economic structures that shape it. ${ }^{44}$ The implication is that urban dirt first has to be understood in relation to the particular material conditions - poverty, neglect, ruination - of specific locales: in this case Dalston. His extension of Douglas's ideas is once again suggestive of tensions between structuralist and phenomenological, symbolic and everyday, understandings of dirt inherent in her account. The implication is that, in the context of the late modern city, the tensions and contradictions between what sociologist Carol Wolkowitz has recently termed 'postmodern and/or poststructural dirt [...] purified through abstraction' and 'the idea of "real dirt", are increasingly apparent. ${ }^{45}$

This brief survey illustrates how Douglas' theory has provoked architectural, urban and spatial thought. These examples show how it has operated as an interpretative frame for thinking about questions of dirt, and varied forms of material evidence for its presence, and its treatment within architecture and urbanism. Put to work within these texts the observations developed in Purity and Danger implicitly evidence a 'gap' in architectural, spatial and urban thinking around constructions of dirt, which in distinct ways each cited author set out to address. Yet through a close reading of the alignments these authors make between Douglas's arguments and critical theory, psychoanalytic theory, feminist and other poststructuralist accounts, we notice weaknesses and inconsistencies in Douglas's theory, as well as certain positive aspects that have generally been underplayed. Although dirt has returned to the architectural agenda, and as a subject for cultural debate, the theoretical concerns of the 1990s have not been adequately resolved. ${ }^{46}$ 


\section{Purity and Danger in the city}

Moving forward, then, and building on these earlier interpretations of Purity and Danger, a hybrid conceptual framework is required for thinking about different kinds of situated evidence for understanding dirt's relationships with architecture and cities. Caution is required in transposing Douglas's discussion of cultural symbols and social phenomena rigidly organised according to religious structures to any new context. This is particularly true in thinking about urban dirt within the specific dynamics of capitalist urbanisation in different times and places. The view of the dirty/low as constitutive of the clean/high is important in classic nineteenth-century accounts of dirt and disorder in the modern socially and spatially stratified European city. ${ }^{47}$ In 'post-industrial' neoliberal urbanism, on the other hand, we have to account for the juxtaposition of low and high class land uses, and the use of stigmatising rhetoric and double-speak in the categorisation of areas as dirty in order to legitimise their redevelopment. As the geographer Guy Baeten has argued, these dystopian discourses conceal the 'complex and contradictory realities' and underlying inequalities that structure urban life. ${ }^{48}$ Urban dystopia serves as the ideological basis for creative destruction. It is therefore important to understand the way that these dystopian constructions operate over time through focusing on specific cases.

In contemporary Western cities such as London, where there is a fascination with the representation and experience of edgy, degraded, 'dirty' urban neighbourhoods, we also need to develop a more sophisticated conceptual frame for understanding dirt's relationship to design and aesthetics. Think of the conversions of abandoned former industrial buildings typical in neoliberal regeneration. Such buildings have often featured design strategies that enhance, rather than conceal, the material textures of their use and pollution, and their qualities of decay. In such contexts Douglas's theory does not offer much insight. Instead, a range of Anglo-American studies of 'grunge aesthetics' (Hal Foster), contextual post-industrial 'dirty realism' (Liane Lefaivre), the 'aesthetics of recycling' (Giuliana Bruno); 'junkspace' (Rem Koolhaas) and the 'urban pastoral' (Julian Stallabrass) are useful; alongside work on the cultural and economic revaluation of industrial spaces and iconographies. ${ }^{49}$

As an object of study, produced through aggregate phenomena, urban dirt calls for an interdisciplinary theoretical framework that elucidates practices of exclusion as they operate simultaneously across different material and social registers. Combining a material culture studies approach with post-Freudian psychoanalytic and neo- 
Marxian models of thinking about dirt may offer new possibilities to address the core weaknesses in Douglas's theory and the complex intersections between the material and the symbolic that she observes.

Purity and Danger is imbued with psychoanalytic concerns, focusing as it does on relationships between subjectivity, culture and society, as manifest in prohibition and taboo. For Freud, whom Douglas describes as a 'magisterial figure', along with order and beauty, cleanliness constituted one of the three prerequisites for the progress of civilisation. He writes that:

There is an unmistakable social factor in the cultural striving for cleanliness [...] which is later justified on grounds of hygiene, but manifested itself before this connection was appreciated. ${ }^{50}$

The 'urge for cleanliness' accompanies man's evolution into an upright posture, setting him apart from animals. The emergence of 'proper' responses of shame and disgust to excrement - 'organic repression' - provides key components of the development of the libido. ${ }^{51}$

Yet while Freudian and post-Freudian psychoanalytic explorations of dirt and cleanliness in architecture have developed Douglas's arguments in important ways, they have largely been confined to discussions of specific architectures of hygiene, rather than being extended to an urban context. ${ }^{52}$ There is still potential in developing, for example, Julia Kristeva's theory of abjection in relation to urbanisation and urban experience, conceiving of the city as a place where we are continuously forced to negotiate the abject - 'what disturbs identity, system, order' - and actively exclude it. ${ }^{53}$ Kristeva developed her theory in relation to Georges Bataille's notion of 'abjection' in the essay 'Abjection et les formes misérables' (abjection and forms of wretchedness), building directly on Douglas's account of dirt. ${ }^{54}$ Where, for Douglas, in response to dirt we are all involved in a perpetual spatial process of arranging and rearranging the environment, abjection is a more violent expulsion of that which is deemed threatening or repulsive. ${ }^{55}$ In the formation of subjectivity, the abject causes strong and apparently 'natural' reactions: a 'revolt of the person against an external menace from which one wants to keep oneself at a distance - it may menace from inside' ${ }^{56}$ These can range from physiological disgust responses to a rotting object to the moral repulsion prompted by news of a horrific crime. ${ }^{57}$ 
Abjection refers to spatialised processes through which the subject, or society, attempts to impose or maintain a state of purity. Importantly, the concept accounts for a level of ambivalence on the part of the subject - the abject may attract as well as repel. Through the notion of 'spaces of abjection', Kristeva's concept has been put to use, in particular, to examine the relationships between marginalised people and the places they are associated with. ${ }^{58}$ The idea of abjection is a powerful notion with which to underpin our thinking about the various displacements performed in the name of urban change. ${ }^{59}$

The abject, in contrast with interpretations of Douglas that polarise the binary between 'dirty' and 'clean', leaves more room for the idea that: 'filth, under certain circumstances, might surprisingly be a good or enjoyable thing, ${ }^{60}$ that one might desire to see and experience abject spaces; that the marginalised may exist next to the mainstream, the excluded next to the included, and that degeneration might be produced within processes of regeneration. Abject urban spaces necessitate such an interpretation in accounting for interactions between notions of material, spatial, psychological and social degradation and systems for imposing, or attempting to achieve, purity. Responses to stigmatised public spaces - including obsessive surveillance, the patrol of boundaries - parallel the process of abjection at a collective scale. For Douglas, the rejected is also powerful and fascinating, but Kristeva's notion of the abject articulates this more clearly.

In addition to anthropological perspectives, and psychoanalytic accounts, another body of work is relevant to thinking about urban dirt: that which adopts an implicit or explicit neo-Marxian theoretical position in the investigation of the production and discourses of urban dirt, degradation and stigmatised spaces within neoliberal urbanisation. ${ }^{61}$ These scholars, rooted in a Lefebvrian tradition of thinking about order and classification in relation to the city, have emphasised the social relationships underpinning the production of different forms of urban dirt and waste matter, relating them to the material and discursive production of nature.

For Marx, as for Freud, dirt is also constitutive of 'civilisation', but for him it is produced within, and integral to, industrial capitalism:

Light, air, etc. - the simplest animal cleanliness - ceases to be a need for man. Dirt - this pollution and putrefaction of man, the sewage (this word is to be 
understood in its literal sense) of civilization - becomes an element of life for him. Universal unnatural neglect, putrefied nature, becomes an element of life for him [original emphasis]. ${ }^{62}$

Isolated from the Promethean technologies that effect the civilising transformation of nature, the worker is forced to live in and on dirt, on the 'putrefied nature' that is the by-product of industrialisation.

Working on urban nature and infrastructure from a neo-Marxian perspective in urban geography, Maria Kaïka and Erik Swyngedouw's discussion of 'urban trash' provides an evocative theoretical departure. Drawing on the work of Mike Davis, these authors articulate a wide range of forms of urban dirt antagonistic to the 'clean and sanitized', visually and spatially orderly, high modern utopian city ideal. On a geographical level, they suggest, there are close relationships between the spatial distribution of different kinds of waste matter, things, excluded people. They describe diverse phenomena that transverse material and metaphorical forms of 'urban trash', emphasising the complex ways in which these are intertwined.

Unlike Douglas, for whom 'dirt' replaces the commodity in unlocking the meaning of a social system, neo-Marxian analyses of dirt and degradation are firmly rooted in the political, economic and historical dynamics behind the production of particular urban spaces and conditions. ${ }^{63}$ For Swyngedouw and Kaïka:

Perpetual change and an ever shifting mosaic of environmentally and socioculturally distinct urban ecologies - varying from the manufactured landscape gardens of gated communities and high technology campuses to the ecological war zones of depressed neighbourhoods with lead-painted walls and asbestos covered ceilings, waste dumps and pollutant-infested areas - still shape the choreography of a capitalist urbanization process. ${ }^{64}$

The suggestion is that, in the context of the late modern city, such juxtapositions are becoming more intense and more visible. Pollutants are themselves seen to have a historically, culturally and geographically specific 'nature'. Analysing these contemporary urban ecologies will require us to understand the 'choreography' of earlier phases of capitalist urbanisation. It may be productive to make connections, for example, between the discourses focused on public health and industrial and organic wastes in the nineteenth century, twenty-first century bacteriological and 
environmental concerns and socio-spatial practices of exclusion as they operate through contemporary 'regeneration'.

In conclusion, if we pay close attention to the uses of Douglas's theory as evidence in architectural, spatial and urban analysis, we note that Purity and Danger both opens and closes down debate. On the one hand Douglas's approach opens up architecture and urbanism to interdisciplinary thinking and bodies of contextual evidence that prioritise the cultural significance of the everyday and the excluded. However, Douglas's theory contains unresolved tensions between material and conceptual evidence, and between dirt as matter or symbol, and these are at the heart of dirt as a research trope. This is nowhere more clear than in cities and processes of capitalist urbanisation, and in late modernity, where dirt and urban degradation are celebrated and aestheticised, even while the social and material displacements of regeneration accelerate at an increasingly rapacious rate. We will be better placed to think beyond Douglas's idiosyncratic structuralism and stimulate new interdisciplinary research on this topic if we work across material culture, psychoanalytic theory and neo-Marxian theories of nature within urbanisation.

\section{Acknowledgments}

Thanks to Laurence Douny and Richard Fardon for discussing Douglas's work with me. I am grateful to Matthew Gandy, Rebecca Ross and the editors and referees of this journal for their comments on earlier versions of this paper. 
Notes

${ }^{1}$ Mary Douglas, Purity and danger: an analysis of the concepts of pollution and taboo, London: Routledge, 2000, first published 1966, p. 36.

${ }^{2}$ As an example of the general esteem for this book, the UK's national broadsheet the Sunday Times included it in a survey of "Makers of the 20th Century" (1991) among the one hundred most influential nonfiction works since 1945;

http://www.timesonline.co.uk/tol/comment/obituaries/article1805952.ece (accessed 08 April 2009).

${ }^{3}$ Douglas, Purity and Danger, p. xviii; Richard Fardon, “Obituary: Dame Mary Douglas", The Guardian, 18 May 2007; Alan Macfarlane, interview with Mary Douglas, February 2006 http://www.youtube.com/watch?v=xl3oMdIRFDs (accessed 20 December 2012).

${ }^{4}$ See, for example, the recent landscape architecture publication Megan Born, Helene Furján and Lily Jencks with Phillip M. Cosby (eds), Dirt, Philadelphia and London: PennDesign and The MIT Press, 2012.

${ }^{5}$ Richard Fardon, 'Margaret Mary Douglas 1921-2007', Proceedings from the British Academy, 166 (2010), pp. 135-58, p. 154.

${ }^{6}$ Mary Douglas, 'Pollution', in M. Douglas (ed.), Implicit meanings: essays in anthropology, London: Routledge, 1975, pp. 47-59, p. 51.

${ }^{7}$ This exchange is written up in Richard Fardon, 'Citations Out of Place, or, Lord Palmerston goes viral in the nineteenth century but gets lost in the twentieth', Anthropology Today Vol. 29, No. 1, February 2013, pp. 25-26.

${ }^{8}$ Anon., 'The Royal Agricultural Society', The Times, 21169 , 16 July 1852, p. 8.

${ }^{9}$ Steven Connor, 'Smear campaigns', A talk given at the Unclean Beings symposium, Wellcome Collection, London, 16 July 2011

http://www.stevenconnor.com/smearcampaigns/ (accessed 19 December 2012).

${ }^{10}$ For an example of the misattribution of the quote see the catalogue to the Wellcome Trust's recent exhibition, Dirt: the filthy reality of everyday life, London: Profile Books, 2011, p. 2.

${ }^{11}$ Richard Fardon, Mary Douglas: an intellectual biography, London: Routledge, 1999, pp. 76, 117.

${ }^{12}$ William A. Cohen and Ryan Johnson (eds.), Filth: Dirt, Disgust and Modern Life, Minneapolis, MN: University of Minnesota Press, p. xi.

Final manuscript of article accepted for publication in Architectural Theory Review 18(1), 2013.

Not to be quoted or reproduced without the author's permission. (C) Ben Campkin, 2013. 
${ }^{13}$ Douglas, "Pollution”, p. 51.

${ }^{14}$ Douglas, Purity and danger, p. 6.

${ }^{15}$ James Wuthnow et al. identify these interests as characteristics of Douglas's approach to culture; James Wuthnow, Davison Hunter, Albert Bergesen and Edith Kurzweil, Cultural analysis: the work of Peter L. Berger, Mary Douglas, Michel Foucault, and Jurgen Habermas, Boston: Routledge and Kegan Paul, 1984, p. 78.

${ }^{16}$ See, for example, Victor Buchli and Gavin Lucas (eds), Archaeologies of the contemporary past, London: Routledge, 2001.

${ }^{17}$ See, for example, Douglas's domestic references to shoes, cooking utensils and bathrooms; Douglas, Purity and danger, pp. 47-8.

${ }^{18}$ Jonathan Culler, 'Junk and rubbish: a semiotic approach', Diacritics, 15 , no. 3 (1985), pp. 2-12, p. 2.

${ }^{19}$ Claude Lévi-Strauss, Tristes Tropiques, trans. John and Doreen Weightman, New York: Atheneum, 1973 (1955).

${ }^{20}$ Wuthnow et al., Cultural analysis, p. 83.

${ }^{21}$ Douglas writes that 'The background of daily life in nursery and kitchen may explain why the metaphors are homely'; Douglas, Purity and Danger, p. xi.

${ }^{22}$ Douglas, Purity and Danger, pp. xi, 1.

${ }^{23}$ Douglas, Purity and Danger, p. xvii.

${ }^{24}$ Michel Foucault, The order of things: an archaeology of the human sciences, London: Routledge, 2003 (1970); David Sibley, Geographies of exclusion: society and difference in the west, London: Routledge, 1995; Wuthnow et al., Cultural analysis.

${ }^{25}$ Culler, 'Junk and rubbish' p. 84; Elizabeth Shove, Comfort, cleanliness and convenience: the social organization of normality, Oxford: Berg, 2003, p. 2.

Douglas's preoccupation with cultural ordering systems, space and signification continued to occupy a central position in her later work which bridged the methodologies of anthropology and literary criticism. This was evident, for example, in her reading of the structure of the text of Leviticus as a spatial 'picture poem' representing the proportions of the Tabernacle and Mount Sinai. Mary Douglas, 'How I got to where I am: from anthropology to "literary criticism", Mary Douglas Seminar Series, Unpublished, University College London Institute of Archaeology (2005).

${ }^{26}$ Douglas, Purity and Danger, p. xiii. 
${ }^{27}$ Douglas, Purity and Danger, p. 2. In her understanding of taboo, Douglas drew on the work of the anthropologist Franz Steiner, who had been her teacher at the University of Oxford; Franz Steiner, Taboo, New York: Philosophical Library, 1956.

${ }^{28}$ Adrian Forty, Objects of Desire: design and society since 1750, London: Thames and Hudson, 1986. For an alternative discussion of hygienism and whiteness in architecture, see Mark Wigley, White Walls, Designer Dresses: the Fashioning of Modern Architecture, Cambridge, MA: The MIT Press, 2001.

${ }^{29}$ Karl Marx, Economic and philosophical manuscripts, Early Writings, Harmondsworth and London: Penguin/New Left Review, 1992 (1844), pp. 359-60.

${ }^{30}$ Katherine Shonfield, 'Glossing with graininess: cross occupations in postwar British film and architecture', The Journal of Architecture 3, no. 4 (1998), p. 356.

${ }^{31}$ Katherine Shonfield, 'Two architectural projects about purity', in Jonathan Hill (ed.), Architecture: the subject is matter, London: Routledge, 2001, p. 37.

${ }^{32}$ Katherine Shonfield: Walls Have Feelings: Architecture, Film and the City, London: Routledge, 2000, p. 154; Shonfield: 'Two architectural projects about purity', p. 37.

${ }^{33}$ Douglas, Purity and Danger, pp. 48, p. 62.

${ }^{34}$ Douglas, Purity and Danger, p. xvii.

${ }^{35}$ Douglas, Purity and Danger, p. 137.

${ }^{36}$ Mark Cousins, 'The ugly (part 1)', AA Files, 28, 1994, pp. 61-6; 'The ugly (part 2)', AA Files 29, 1995, pp. 3-6; 'The ugly (Part 3)', AA Files, 30, 1995, pp. 65-8.

${ }^{37}$ Cousins: 'The ugly (part 1)', p. 63.

${ }^{38}$ Cousins: 'The ugly (part 1)', p. 62.

${ }^{39}$ Cousins, 'The ugly (part 1)', p. 63

${ }^{40}$ Joseph Schumpeter, Capitalism, Socialism and Democracy, New York: Harper Perennial, 2008 (1942), p. 83.

${ }^{41}$ Sibley, Geographies of exclusion; for comparison in architecture, see Gil Doron, 'The Dead Zone and the Architecture of Transgression', City: Analysis of Urban Trends, Theory, Culture, Policy, Action 4, no. 2 (2000), pp. 247-63.

${ }^{42}$ Patrick Wright, A journey through ruins: the last days of London, London: Radius, 1991. Dalston in northeast London is currently subject to intensifying processes of gentrification. 
${ }^{43}$ Wright, A journey through ruins, pp. 241, 237.

${ }^{44}$ Wright, A journey through ruins, p. 31.

${ }^{45}$ Carol Wolkowitz: 'Linguistic leakiness or really dirty? Dirt in social theory', in Ben Campkin and Rosie Cox (eds), Dirt: New Geographies of Cleanliness and Contamination, London: I.B. Tauris, 2007, pp. 15-24, p. 15.

${ }^{46}$ See, for example, Wellcome Trust, Dirt: the filthy reality of everyday life, London: Profile Books, 2011; and Born, et al. (eds), Dirt.

${ }^{47}$ For example, Stallybrass and White explore metaphors of height and visibility in the mapping of the city by writers such as Chadwick, Mayhew, Marx, Engels, Freud, Baudelaire and Dickens. They argue that 'the axis of the body is transcoded through the axis of the city, and whilst the bodily low is "forgotten", the city's low becomes a site of obsessive preoccupation, a preoccupation which is itself intimately conceptualised in terms of discourses of the body'; Peter Stallyrass and Allon White, The politics and poetics of transgression, London: Methuen, 1986, p. 145. In this period, as evidenced through the texts of reformers, novelists and other urban commentators, new social hierarchies and spatial boundaries in urban space (high/low, suburb/slum) are both instituted and transgressed; Stallybrass and White, The politics and poetics of transgression, p. 127. However, geographer Steve Pile has recently problematised the tendency to overemphasise the vertical hierarchical organisation of urban space in relation to dirt and waste matter, in which the underground is equated with the lowest forms of filth. The sophistication of underground networks, Pile emphasises, provides an index of urban progress equivalent to tall or spectacular structures; Steve Pile, 'The un(known) city... or, an urban geography of what lies buried below the surface', in Iain Borden, Joe Kerr, Jane Rendell and Alicia Pivaro (eds), The unknown city: contesting architecture and social space, Cambridge, MA: The MIT Press, 2001, pp. 262-79.

${ }^{48}$ Guy Baeten, 'Hypochondriac geographies of the city and the new urban dystopia', City 6, no. 1 (2002), pp. 103-15, pp. 111-12.

${ }^{49}$ Guiliana Bruno, 'Ramble city: postmodernism and Blade Runner', OCTOBER 41 (1987), pp. 61-74; Hal Foster: 'Why all the hoopla?', London Review of Books 23/16, 2001, pp. 24-26; Rem Koolhaas, 'Junkspace', OCTOBER 100 (2002), pp. 175-90; Liane Lefaivre, 'Dirty realism in European architecture today', Design Book Review, 17 (1989), pp. 17-20; Julian Stallabrass, High Art Lite: British Art in the 1990s, London: Verso, 1999.

${ }^{50}$ Sigmund Freud, Civilization and its discontents, London: Penguin, 2002 (1930), p. 41, n. 1.

${ }^{51}$ Leo Bersani, The Freudian body: psychoanalysis and art, New York: Columbia University Press, 1986, p. 17.

${ }^{52}$ Lorens Holm, 'eS aitcH eYe Tee', The Journal of Architecture 12, no. 4 (2007), p. 428; Nadir Lahiji and Daniel S. Friedman, 'At the sink: architecture in abjection', in 
Nadir Lahiji and Daniel S. Friedman (eds), Plumbing: sounding modern architecture, New York: Princeton Architectural Press, 1997, p. 42.

${ }^{53}$ Julia Kristeva, Powers of Horror: an essay on abjection, New York: Columbia University Press, 1982. Kristeva writes (on p. 4) that 'It is thus not lack of cleanliness or health that causes abjection but what disturbs identity, system, order. What does not respect borders, positions, rules. The in-between, the ambiguous, the composite'.

${ }^{54}$ Georges Bataille, 'L'Abjection et les formes misérables', in Georges Bataille (ed.), Essais de sociologie, oeuvres complètes, Paris: Gallimard, 1970; Kristeva: Powers of Horror. According to Fardon, Douglas did not feel that Kristeva's theory had added significantly to her own.

${ }^{55}$ Douglas, Purity and Danger, p. 2. Steve Pile describes the process of abjection thus: 'Children learn to displace dangerous or unwanted feelings onto others - others who are perceived to be different. These feelings are simultaneously social, bodily and spatial [...] In abjection, senses of revulsion over bodily materials and feelings are established. The subject wants to expel whatever is reviled, but is powerless to achieve it: thus, for example, the desire to be completely clean all the time cannot be achieved, purity cannot be maintained. Abjection, then, is a perpetual condition of surveillance, maintenance and policing of impossible "cleanliness".' Steve Pile, The body and the city: psychoanalysis, space and subjectivity, London: Routledge, 1996, p. 90 .

${ }^{56}$ Kristeva, quoted in Buchli and Lucas (eds), Archaeologies of the contemporary past, p. 11.

${ }^{57}$ Jennifer Robinson, 'Feminism and the spaces of transformation', Transactions of the Institute of British Geographers: New Series 25, no. 3 (2000), pp. 285-301.

${ }^{58}$ In a number of spatially oriented disciplines such as cultural studies, geography, architectural and art history, scholars have used Kristeva's theory to examine spaces of abjection, marginalised communities and the spatiality of hygiene. See for example Victor Burgin, In/different spaces: place and memory in visual culture, London: University of California Press, 1996; Lahiji and Friedman, 'At the sink'; Anne McClintock, Imperial leather: race, gender and sexuality in the colonial contest, London and New York: Routledge, 1995; Barbara Penner and Olga Gershenson (eds) Ladies and gents: public toilets and gender, Philadelphia PA, Temple University Press, 2009; Robinson, 'Feminism and the spaces of transformation'; Sibley, Geographies of exclusion; Robbert D. Wilton, 'The constitution of difference: space and psyche in landscapes of exclusion', Geoforum 29, no. 2 (1998), pp. 173-85; Henry Urbach, 'Closets, clothes, disClosure', in Jane Rendell, Barbara Penner, and Iain Borden (eds), Gender space architecture, London and New York: Routledge, 2000, pp. 342-52.

${ }^{59}$ See Ben Campkin, Remaking London: Decline and Regeneration in Urban Culture, London: IB Tauris, forthcoming 2013.

${ }^{60}$ Cohen and Johnson, Filth, p. xxviii. 
${ }^{61}$ Baeten, 'Hypochondriac geographies of the city'; Matthew Gandy, 'The Paris sewers and the rationalization of urban space', Transactions of the Institute of British Geographers, 24, no. 1, 23-44; Matthew Gandy, Concrete and clay: reworking nature in New York City, Cambridge, MA: MIT Press, 2002; David Gissen, Atmospheres of late-modernity: the urban production of indoor air in New York City, 1963-2003, unpublished Ph.D dissertation, Department of Geography, University College London, 2007; David Gissen, Subnature: architecture's other environments, New York: Princeton Architectural Press, 2009; Maria Kaïka, City of flows: modernity, nature and the city, London and New York: Routledge, 2005; Kaïka and Swyngedouw, 'Fetishizing the modern city: the phantasmagoria of urban technological networks', International Journal of Urban and Regional Research 24/1 (2000), pp. 120-38; Erik Swyngedouw and Maria Kaiika, 'The environment of the city ... or the urbanization of nature', in Gary Bridge and Sophie Watson (eds.), The Blackwell Companion to the City, Oxford: Blackwell, 2000, pp. 567-80.

${ }^{62}$ Karl Marx, 'Economic and philosophical manuscripts', in Karl Marx, Early Writings, London: Penguin/New Left Review, 1992 (1844), pp. 359-60. Thanks to Nicholas Beech for pointing me to this quote.

${ }^{63}$ Wuthnow et al. write that 'For Mary Douglas the artifact is simple, obvious and everyday, much like Marx's commodity and Durkheim's totem'; Wuthnow et al., Cultural analysis, p. 85.

${ }^{64}$ Swyngedouw and Kaïka: 'The environment of the city...or the urbanization of nature', p. 570. 